\title{
Analysis of the Behavior of Bureaucrats on Service Quality
}

\author{
Andi Asrijal ${ }^{1}$, Syahruddin ${ }^{2}$, Awaluddin Amrin ${ }^{3}$ \\ ${ }^{1,3}$ Sekolah Tinggi Ilmi Adminsitrasi Puangrimaggalatung \\ ${ }^{2}$ STKIP Muhammadiyah Bone \\ Email: andiasri1397@gmail.com
}

(Received: August 2020; revised: November 2020; published: November 2020)

\begin{abstract}
Until now, bureaucratic behavior cannot be separated from the unpleasant terms addressed to bureaucrats who work in government. This is due to the low understanding of these bureaucrats in carrying out their duties. The purpose of the research carried out at the One Stop Investment Service and One Stop Services in Bone Regency is to find out what kind of behavior the bureaucrats are in providing services, how the quality of services provided and the extent to which bureaucrats' behavior affects the quality of Licensing Services at the Investment Service and Integrated Services One. Pintu District Bone. To answer these questions, the stages of the research method are used, starting from theoretical and empirical studies, preparation of proposals, testing the validity and reliability of the instrument, data collection, analysis and discussion. The data analysis used was qualitative. The mandatory output is in the form of a scientific publication in a national journal. The results showed that bureaucratic behavior seen from the level of politeness in serving the community was considered high, the behavior of bureaucrats with disciplinary and caring aspects was also in the very high category so that it significantly affected the quality of service at the One Stop Investment and One Stop Services, Bone Regency
\end{abstract}

Keywords: Public accountability, service quality, public service, bureaucratic behavior

\section{INTRODUCTION}

Public services are one of the functions of government administration carried out by government officials where the public service sector is growing rapidly (Ayu, Niswaty, Darwis, \& Arhas, 2019; Daswati, Samad, \& Wekke, 2018; Niswaty, 2013), both in terms of the scale of production and diversity. This development certainly cannot be separated from the increasing public demand. The impact of such rapid development is the birth of new needs that cannot be managed properly by the traditional public accountability system. The traditional public accountability system only relies on formal relations between the legislature, the government bureaucracy, and the public service providers themselves (Akib \& Ihsan, 2017; Rengifurwarin, Akib, \& Salam, 2018).

The One-Stop Integrated Service and Investment Service for Bone Regency is an implementing agency for One-Stop Services which has a role in providing public service reform, namely simplifying licensing services; systems and procedures, requirements, accelerating time and cost certainty, increasing regional competitiveness, encouraging the investment and business climate in the regions, increasing Regional Original Income and preventing Corruption, Collusion and Nepotism.

Empirically and actually, the services received by the community have not fully satisfied and fulfilled the people's needs (Daraba, Subianto, \& Salam, 2018; Lee \& Chung, 2016; Stevenson, 2007). This can be seen from the many complaints from the community, namely 


\section{Jurnal Administrare: Jurnal Pemikiran Ilmiah dan Pendidikan Administrasi Perkantoran Volume 7 Number 2 July- December 2020. Pages 245-252}

unclear management costs, resolution that takes a long time, and sometimes permits issued are only recommendations, such as development permits, while the IMB itself never exists. In addition, the issuance of IMB recommendations violated many regulations so that the community had to bear the consequences of the negligence of the officers (employees). Likewise, for other licensing arrangements, there are still unreasonable fees and processing times are too long and lengthy, making it difficult for the community..

Public service is the fulfillment of people's wants and needs by state administrators (Mirdawati, Niswaty, Darwis, \& Salam, 2018). The state is founded by the public (society), of course, with the aim of improving the welfare of the community. In essence, the state in this case the government (bureaucrats) must be able to meet the needs of the community. The needs, in this case, are not individual needs, but various needs that are actually expected by the community, for example, the needs for education, health, and other public services.

Government belongs to the community in terms of services and will be created if bureaucrats can redefine their duties and functions (Isma, Darwis, Saleh, \& Salam, 2017; Sulanjari, 2020; Yusriadi \& Farida, 2019). It should be assumed that many bureaucrats do not understand with certainty or at least do not understand the philosophy of the services they will provide so that the public services that the people dream of are far from the reality they experience. The behavior of bureaucrats in public services, in a practical-operation manner (Kartasasmita, 2016) " first, bureaucrats must build public participation; second, bureaucrats should not tend to be oriented towards the strong but must be more towards the weak and less empowered (the under privileged); third, the role of the state apparatus must shift from controlling to directing and from giving to empowering; fourth, developing transparency and accountability".

Society, at all times always demands quality public services from bureaucrats, although these demands are often not in accordance with expectations because empirically, public services that have occurred so far are still characterized: convoluted, slow, expensive, and tiring. (Aneta, Aneta, \& Dama, 2019; Saputra, Pratama, \& Orbawati, 2019). This tendency occurs because the community is still positioned as the party that "serves" not the one served in the real sense. Services that are supposed to be aimed at the general public are sometimes reversed into public service to the state, even though the state is actually established for the benefit of the people who founded it.

The One-Stop Integrated Service and Investment Service for Bone Regency is an implementing agency for One Stop Services which has a role in providing public service reform, namely simplifying licensing services; systems and procedures, requirements, accelerating time and cost certainty, increasing regional competitiveness, encouraging the investment and business climate in the regions, increasing Regional Original Income) and preventing Corruption, Collusion and Nepotism. The results of preliminary observations indicate that all types of services require a longer time than the predetermined standard of time, there are even types of services that should be completed in 1 day, in fact, they are completed for 3 days or even 1 week. This of course is greatly influenced by the behavior of the bureaucrats. This bureaucratic behavior is reflected in the low level of discipline such as arriving, resting, and returning home not on time, always procrastinating in providing services, and being discriminating in providing services..

The government is a government organization that has the authority to provide public services and carry out the obligation to meet community needs, namely service needs. The 
purpose of forming the government is to provide services to the community. The services provided to the community should reflect a sense of justice for all members of society (Siahaan, 2014).

The Office of Investment and One-Stop Integrated Service in Bone Regency is the main pillar in providing services to the community. Therefore, bureaucrats must be able to show good and responsible behavior. But in reality, the behavior of bureaucrats is still far from the expectations of the community, which is reflected in the low quality of services received by the community

\section{METHOD}

This research is survey research conducted to take generalizations from less in-depth sample observations. Based on the level of explanation, this study is an associative study or relationship which aims to determine the relationship between variables in this case the behavior of bureaucrats and service quality.

Primary data from this study are people who are currently or have received services for licensing requests at the Investment and One-Stop Integrated Services Office of Bone Regency. Determination of the sample using nonprobability sampling means that it does not attempt to provide equal opportunities for the population to be sampled. The technique used is incidental sampling, meaning that the sample appointed at the time of the research is people who are currently or have received services of approximately 35 people. However, if the number of samples is deemed to have met the needs, the data collection activities from the samples are stopped. For data completeness, check and recheck were used to research informants, namely the Head of the Office of the Head of the One-Stop Investment and One-Stop Services Division of Bone Regency which was carried out using a purposive method, namely direct appointment because it was considered to know for sure about the problem being studied.

For the purposes of this study, two instruments were used, namely a questionnaire and an interview guide. This instrument is a non-test instrument that is used only to measure a person's attitudes or perceptions of the questions asked about the variables to be measured, namely bureaucratic behavior and service quality. Meanwhile, to answer the above problems used descriptive statistical analysis with frequency tables and inferential statistical simple regression methods with the help of SPSS 20.0. The analysis starts with data collection and continues until the study ends..

\section{RESULT AND DISCUSSION}

The data analysis in this study was conducted to see the effect of three independent variables, namely politeness, discipline, and concern for the dependent variable, namely service quality using multiple linear regression analysis. Multiple linear regression analysis was performed using the help of the SPSS for Windows 20 program 
248 Jurnal Administrare: Jurnal Pemikiran Ilmiah dan Pendidikan Administrasi Perkantoran

Volume 7 Number 2 July- December 2020. Pages 245-252

Table 1.

Regression Coefficient

\begin{tabular}{rrrr}
\hline \multirow{2}{*}{ Model } & \multicolumn{2}{c}{ Unstandardized Coefficients } \\
\cline { 3 - 4 } 1 & (Constant) & B & Std. Error \\
& Courtesy & 1,765 & 1,429 \\
& Discipline &, 295 &, 094 \\
& Concern &, 331 &, 123 \\
&, 333 &, 152 \\
\hline
\end{tabular}

Table Source: SPSS for Windows 20

The results of the F test carried out to see the effect of the three variables of bureaucrat behavior together on service quality are described in the following table:

Table 2.

F Test Results

ANOVA $^{\text {a }}$

\begin{tabular}{lrrrrr}
\hline Model & $\begin{array}{c}\text { Sum of } \\
\text { Squares }\end{array}$ & df & $\begin{array}{c}\text { Mean } \\
\text { Square }\end{array}$ & F & Sig. \\
\hline 1. Regression & 454,206 & 3 & 151,402 & 69,348 &, $000^{\mathrm{b}}$ \\
Residual & 67,680 & 31 & 2,183 & & \\
Total & 521,886 & 34 & & & \\
\hline
\end{tabular}

Source: SPSS for Windows 20

From table 2, it can be seen that the significance value of the $\mathrm{F}$ test of $0.000 \mathrm{~b}$ is smaller than the significance value, this means that $\mathrm{H}_{0}$ is rejected and $\mathrm{H}_{\mathrm{a}}$ is accepted, which means that all independent variables together have a significant effect on service quality.

The t-test results can be seen in the following table, where the significance value is obtained by comparing the value of 0.05 or by comparing the calculated $t$ value with the $t$ value

Table 3.

Results of Multiple Linear Regression Analysis

\begin{tabular}{ccccccc}
\hline \multirow{2}{*}{ Model } & \multicolumn{2}{c}{$\begin{array}{c}\text { Unstandardized } \\
\text { Coefficients }\end{array}$} & \multicolumn{2}{c}{$\begin{array}{c}\text { standardized } \\
\text { Coefficients }\end{array}$} & \multirow{2}{*}{$\mathrm{t}$} & \multirow{2}{*}{ Sig. } \\
\cline { 3 - 5 } & \multicolumn{2}{c}{ B } & Std. Error & Beta & & \\
\hline 1 & (Constant) & 1,765 & 1,429 & & 1,235 &, 226 \\
& Courtesy &, 295 &, 094 &, 337 & 3,143 &, 004 \\
& Discipline &, 331 &, 123 &, 372 & 2,685 &, 012 \\
& Concern &, 333 &, 152 &, 293 & 2,188 &, 036 \\
\hline
\end{tabular}

Source: SPSS for Windows 20

\section{The Influence of the Aspects of Courtesy on the Quality of Public Services}

In the politeness variable (X1), the significance value of 0.004 is smaller than the value, this means that $\mathrm{HO}$ is rejected and $\mathrm{Ha}$ is accepted. Thus, politeness has a significant effect on service quality performance. This is because officers who are stationed at service counters have received instructions from their leaders regarding the importance of ethics in service. Giving 
respect to society is not an act that humiliates oneself or an institution, but on the contrary, people will feel respected and open, and will then provide any information regarding what they are taking care of. Greet the applicant, provide an understanding of the licensing procedure politely, and serve them patiently and guide them to understand filling out the form. From the table above shows that the results of the study place politeness very significantly in influencing the level of service quality.

\section{The Influence of Discipline Aspects on the Quality of Public Services}

Based on the test results, the effect of politeness of the bureaucrats who served at the service counter at the One-Stop Investment and One-Stop Services Office of Bone Regency shows that there is a very significant influence on the quality of public services, either directly or indirectly. (Sinambela, 2011) defines "employee performance as an employee's ability to do something with certain skills. Every particular employee must have the ability and expertise to complete the job with good abilities and expertise, it will improve the quality of the performance of these employees and will have an impact on improving the quality of public services. From the table T-test above shows that in the politeness variable (X1), the significance value of 0.004 is smaller than the value of $\alpha=0.05$, this means that $\mathrm{H} 0$ is rejected and $\mathrm{Ha}$ is accepted. Thus, politeness has a significant effect on service quality performance.

\section{The Influence of Concern Aspects of the Quality of Public Services}

In the caring variable (X3), the significance value of 0.036 is smaller than the value, this means that $\mathrm{HO}$ is rejected and $\mathrm{Ha}$ is accepted. Thus, care has a significant effect on service quality performance. At this level, concern also has a very significant effect on the quality of service, this is based on the fact that the community is well served, the incomplete application files are arranged in such a way and submitted to the applicant about what deficiencies need to be completed so that the files can be processed as soon as possible. Various complaints submitted by the applicants were also responded to with full responsibility, the authorities are also very responsive to situations where when they see applicants who are confused or do not understand, they will immediately be approached and then lead them to the counters they should have visited. Activities like this then give the community a sense of empathy for the services of the officials, which then significantly has a very good effect on service quality.

\section{The Influence of Courtesy Aspects, Discipline Aspects and Concern Aspects of Public Service Quality}

The magnitude of the influence of the three variables of bureaucratic behavior, namely politeness (X1), discipline (X2), care (X3) together on service quality can be seen in the value of the correlation coefficient $(\mathrm{R})$ and the coefficient of determination (R2) in the following table:

Tabel 4.

Hasil Analisis Determinasi

\begin{tabular}{ccccccc}
\hline Mode 1 & $\mathrm{R}$ & $\mathrm{R}$ Square & $\begin{array}{l}\text { Adjusted } \\
\text { Square }\end{array}$ & $\begin{array}{l}\text { Std. Error of } \\
\text { the Estimate }\end{array}$ & $\begin{array}{l}\text { Durbin- } \\
\text { Watson }\end{array}$ \\
\hline 1 &, $933^{\mathrm{a}}$ &, 870 &, 858 & 1,47757 & 2,308 \\
\hline
\end{tabular}

Source: SPSS for Windows 20 
250 Jurnal Administrare: Jurnal Pemikiran Ilmiah dan Pendidikan Administrasi Perkantoran
Volume 7 Number 2 July- December 2020. Pages 245-252

From table 4 above, it can be seen that the coefficient of determination is 0.870 . This means that the three variables of bureaucratic behavior together have an influence of $0.870 \times 100 \%=87 \%$. While the remaining $13 \%$ is influenced by other factors not included in the study.

\section{Discussion}

\section{The Influence of the Aspects of Courtesy on the Quality of Public Services}

Based on the test results, the effect of politeness of the bureaucrats who served at the service counter at the One Stop Investment and One Stop Services Office of Bone Regency shows that there is a very significant influence on the quality of public services, either directly or indirectly. (Sinambela, 2011) defines employee performance as an employee's ability to do something with certain skills. Every particular employee must have the ability and expertise to complete the job with good abilities and expertise, it will improve the quality of the performance of these employees and will have an impact on improving the quality of public services. From the table T-test above shows that in the politeness variable (X1), the significance value of 0.004 is smaller than the value of $\alpha=0.05$, this means that $\mathrm{H} 0$ is rejected and $\mathrm{Ha}$ is accepted. Thus, politeness has a significant effect on service quality performance.

\section{The Influence of Discipline Aspects on the Quality of Public Services}

The test results show that the caring aspect also has an important role in providing results in quality public services. This is because the bureaucrats have described all the instructions that have been given previously.

(Siahaan, 2014) concluded the results of the study that the government is a government organization that has the authority to provide public services and carry out the obligation to meet community needs, namely service needs. The purpose of forming the government is to provide services to the community. The services provided to the community should reflect a sense of justice for all members of society.

\section{The Influence of Concern Aspects of the Quality of Public Services}

In the caring variable (X3), the significance value of 0.036 is smaller than the value of $\alpha$ $=0.05$, this means that $\mathrm{HO}$ is rejected and $\mathrm{Ha}$ is accepted. Thus, care has a significant effect on service quality performance. At this level, concern also has a very significant effect on the quality of service, this is based on the fact that the community is well served, the incomplete application files are arranged in such a way and submitted to the applicant about what deficiencies need to be completed so that the files can be processed as soon as possible. Various complaints submitted by the applicants were also responded to with full responsibility, the authorities are also very responsive to situations where when they see applicants who are confused or do not understand, they will immediately be approached and then lead them to the counters they should have visited. Activities like this then give the community a sense of empathy for the services of the officials, which then significantly has a very good effect on service quality. 


\section{The Influence of Courtesy Aspects, Discipline Aspects and Concern Aspects of Public Service Quality}

Based on the test results, both the results of the T-test and the results of the F test, show that the three variables of bureaucratic behavior, namely the aspects of politeness, disciplinary and caring aspects, jointly affect the quality of service at the Investment Service and One-Stop Integrated Service in Bone Regency There are three indicators of customer satisfaction that lie in the five dimensions of service quality, namely: reliability, the ability of the institution to provide services as promised accurately and reliably, such as timeliness, sympathetic attitude, and others; responsiveness, a policy to assist and provide fast and appropriate services to the public, with clear information delivery, assurance or assurance, knowledge, politeness and the ability of institutional employees to foster customer trust in the institution.

\section{CONCLUSION}

The government, in this case, the related agency, must be able to act as a bridge as well as a facilitator in every licensing arrangement. The bureaucrats who have been regarded as one of the causes for the decline in service quality have shown very encouraging results. the staff assigned to the file reception counters have carried out their duties properly and have explained all technical instructions, both concerning discipline, courtesy, and care. This happened after several staff who were deemed less qualified were transferred and replaced by highly dedicated officers. There are three behavioral aspects that are the measurement of the study and all three fall into the high category and greatly affect the quality of service. it means that the behavior of bureaucrats towards service quality is in accordance with the expectations of society. Although overall there is still a need for guidance and guidance because this is still in the transition stage of changing the mindset so that in the future it will be even better

\section{REFERENCES}

Akib, H., \& Ihsan, A. (2017). Bureaucratic reform in public service: A case study on the one stop-integrated service. Mediterranean Journal of Social Sciences, 8(2), 253258.

Aneta, A., Aneta, Y., \& Dama, H. (2019). Institutional Problems in Regional Public Services. Jurnal Ilmiah Ilmu Administrasi Publik, 8(2), 79-86.

Ayu, A., Niswaty, R., Darwis, M., \& Arhas, S. H. (2019). Applying the Principles of Good Governance in the Efforts of Guiding Out-of-School Children at Social Service Offices Takalar Regency. Jurnal Office, 5(2), 51-58.

Daraba, D., Subianto, A. B., \& Salam, R. (2018). An effort to Improve the Quality of Workers at the Makassar city Department of Employment Services. Jurnal Ilmiah Ilmu Administrasi Publik, 8(1), 21-26.

Daswati, Samad, \& Wekke. (2018). Collaborative Governance Dalam Pengelolaan Integrated Community Shelter Pasca Bencana Di Kota Palu Collaborative Governance in the management of Integrated Community Shelters post disaster ( 
252 | Jurnal Administrare: Jurnal Pemikiran Ilmiah dan Pendidikan Administrasi Perkantoran Volume 7 Number 2 July- December 2020. Pages 245-252

ICS ) in the City of Palu.

Isma, E. W., Darwis, M., Saleh, S., \& Salam, R. (2017). Kualitas Pelayanan Administrasi pada Puskesmas Gattareng Kecamatan Gantarang Kabupaten Bulukumba. JURNAL ILMU ADMINISTRASI PERKANTORAN (JIAP), 21-28.

Kartasasmita, G. (2016). Pemberdayaan Masyarakat dalam Rangka Pengembangan Ekonomi Rakyat. Jurnal Bestari, (20).

Lee, S.-Y., \& Chung, M. (2016). An exploratory study on construction of electronic government as platform with customized public services: to improve administrative aspects of administrative processes and information systems. Journal of Digital Convergence, 14(1), 1-11.

Mirdawati, J., Niswaty, R., Darwis, M., \& Salam, R. (2018). Keefektifan Pelayanan IMB Pada Kantor Dinas Penanaman Modal dan Pelayanan Terpadu Satu Pintu Kota Makassar The effectiveness of IMB Services at the Makassar City Investment Office and One Door Integrated Services at Makassar City.

Niswaty, R. (2013). Demokratisasi dan efektivitas penyelenggaraan pemilihan umum kepala daerah Kabupaten Gowa oleh Komisi Pemilihan Umum Daerah: laporan hasil penelitian disertasi doktor: tahun ke 1 dari rencana 1 tahun. Fakultas Ilmu Sosial, Universitas Negeri Makassar.

Rengifurwarin, Z. A., Akib, H., \& Salam, R. (2018). Snapshot of public service quality in the center for integrated business service (CIBS), cooperative micro small and medium enterprises (CMSME), Maluku Province, Indonesia. Journal of Entrepreneurship Education, 21(3), 1-12.

Saputra, A. D., Pratama, A. B., \& Orbawati, E. B. (2019). Public Service Transformation (A Case Study of Online Single Submission at The Office of Investment and Integrated Services Magelang Municipality). Jurnal Ilmiah Ilmu Administrasi Publik, 9(1), 76-86.

Siahaan, R. (2014). Pengaruh Perilaku Birokrasi Terhadap Kualitas Pelayanan Publik (Studi di Badan Pelayanan Perijinan Terpadu (BP2T) Kota Malang). Universitas Brawijaya.

Sinambela, L. P. (2011). Reformasi Pelayanan Publik: Teori, Kebijakan dan Implementasi. In Bumi Aksara.

Stevenson, D. (2007). Privatization of State Administrative Services. La. L. Rev., 68, 1285.

Sulanjari, D. Y. (2020). E-Government Implementation in the Education Zone Service in Makassar City. Jurnal Ad'ministrare, 6(2), 153-158.

Yusriadi, Y., \& Farida, U. (2019). Bureaucracy Performance in Public Services in Indonesia. Jurnal Ad'ministrare, 6(1), 17-24. 